\title{
EVALUASI KESUBURAN TANAH PADA BERBAGAI TUTUPAN LAHAN DI KEBUN RAYA BOGOR
}

\section{Evaluation of soil fertility in various land covers at Bogor Botanic Gardens}

\author{
Arief Noor Rachmadiyanto*, Irvan Fadli Wanda, Dipta Sumeru Rinandio, Mahat Magandhi \\ Pusat Penelitian Konservasi Tumbuhan dan Kebun Raya, LIPI \\ Jl. Ir. H. Juanda No.13 Kota Bogor, Jawa Barat, Indonesia 16003 \\ *Email: arief.noor.rachmadiyanto@lipi.go.id
}

Diterima/Received: 16 April 2020; Disetujui/Accepted: 30 Juni 2020

\begin{abstract}
Bogor Botanic Gardens (BBG), which one of the oldest Botanic Garden in Southeast Asia has more than 12,000 specimen of plants collections. The state soil fertility management is essential for collection in BBG, but currently the soil fertility in BBG unknown. This study aims to evaluate soil fertility condition with analysis of soil chemical and physical properties. Expected to a consideration in the collection management fertility herbs optimal expected to grow. The study conducted in March-October 2019. Methods used is land survey detail $(1: 5,000-$ $1: 10,000$ of scales) to a special purpose fertility land the chemistry and physics properties. The sampling location determined by overlaying map of the garden, land cover (grass, litter, and without litter) and contour. The soil samples are collected using the sample ring and disturbed soil method. Variables were observed consisting of texture, $\mathrm{pH}$, cation exchange capacity, total nitrogen, $\mathrm{P}_{2} \mathrm{O}_{5}$ available, $\mathrm{K}_{2} \mathrm{O}$ available, and $\mathrm{C}$ organic. The results showed soil fertility class in BBG had low until medium fertility $(94.07 \%)$ at various type of land cover. Covers litter having soil fertility higher compared to others (45.32\%) (low-medium category). Advice that can be recommended is the litter zoning management, litter so that the process of decomposing organic cycle runs covered.
\end{abstract}

Keywords: Bogor Botanic Gardens, land cover, soil fertility

\begin{abstract}
Abstrak
Kebun Raya Bogor (KRB) merupakan salah satu kebun raya tertua di Asia Tenggara yang memiliki jumlah koleksi tumbuhan mencapai lebih dari 12.000 spesimen. Kondisi kesuburan tanah sangat penting untuk pengelolaan koleksi di KRB, namun saat ini kondisi kesuburan tanah di KRB belum diketahui. Tujuan penelitian ini adalah untuk mengetahui kondisi kesuburan tanah, meliputi sifat kimia dan fisika tanah. Diharapkan dapat menjadi bahan pertimbangan dalam manajemen kesuburan tanah sehingga tumbuhan koleksi dapat tumbuh dengan optimal. Penelitian dilaksanakan pada bulan Maret-Oktober 2019. Metode yang digunakan adalah survei tanah detail (skala 1:5.000-1:10.000) dengan tujuan khusus yaitu kesuburan kimia dan fisika tanah. Pengambilan sampel berdasarkan overlay dari peta kebun, tutupan lahan (rumput; serasah, dan tanpa serasah) dan kontur. Sampel yang diambil dengan metode ring sampel dan tanah terganggu. Variabel pengamatannya mencakup tekstur, $\mathrm{pH}$, kapasitas tukar kation, nitrogen total, $\mathrm{P}_{2} \mathrm{O}_{5}$ tersedia, $\mathrm{K}_{2} \mathrm{O}$ tersedia, dan $\mathrm{C}$ organik. Hasil penelitian menunjukkan bahwa kondisi kesuburan tanah di KRB cenderung rendah hingga sedang $(94,07 \%)$ pada berbagai tipe tutupan lahan. Tutupan serasah memiliki kesuburan tanah lebih tinggi dibandingkan lainnya $(45,32 \%)$ (kategori rendahsedang). Saran yang dapat direkomendasikan adalah pengelolaan zonasi serasah, sehingga proses dekomposisi berjalan dengan siklus hara tertutup.
\end{abstract}

Kata kunci: Kebun Raya Bogor, kesuburan tanah, tutupan lahan 


\section{PENDAHULUAN}

Kebun raya merupakan area yang memiliki koleksi tumbuhan hidup yang ditata berdasarkan pola tertentu dan terdokumentasi untuk tujuan konservasi, penelitian, pendidikan, wisata, dan jasa lingkungan (Perpres No. 93 Tahun 2011; BGCI 2020). Pada awalnya, kebun raya dibangun untuk memperkenalkan tumbuhan obat, selanjutnya kebun raya menjadi areal koleksi penemuan benih tumbuhan dari daerah lain (Powledge 2011). Dalam perkembangan selanjutnya, kebun raya memiliki fungsi penting untuk konservasi tumbuhan ex situ (Oldfield \& Newton 2012; Mounce et al. 2017; Widyatmoko \& Risna 2017; da Costa et al. 2018), penelitian (Hu et al. 2017; Chen \& Sun 2018), pendidikan lingkungan (Yang \& Chen 2017; Zelenika et al. 2018), wisata (Karasah \& Var 2013; Hadi et al. 2017), dan jasa lingkungan, seperti penyerapan karbon (Agonafir \& Abera 2017; Gratani et al. 2019).

Kebun Raya Bogor (KRB) merupakan kebun raya tertua di Asia Tenggara dengan lebih dari 12.000 spesimen koleksi tumbuhan (Registrasi 2019). Peran tumbuhan koleksi di KRB sangat penting untuk mengimplementasikan fungsi-fungsi kebun raya. Sejumlah jenis tumbuhan langka dalam daftar merah International Union for Conservation of Nature's (IUCN) telah menjadi koleksi hidup di KRB yang menunjukkan adanya fungsi konservasi ex situ (Purnomo et al. 2015b; Widyatmoko \& Risna 2017). Koleksi tumbuhan juga menjadi objek penelitian yang menunjukkan KRB mengimplementasikan fungsi penelitian (Handayani 2016; Yudaputra et al. 2017; Irawati et al. 2017), penyimpanan karbon (Purnomo et al. 2015a), dan penyerapan $\mathrm{CO}_{2}, \mathrm{NO}_{2}$, dan debu (Zahriyani \& Yuwono 2014). Keberadaan koleksi tumbuhan menjadi daya tarik bagi wisatawan dan objek pendidikan lingkungan. Hal tersebut menunjukkan bahwa pengelolaan area koleksi tumbuhan di KRB perlu dilakukan. Penyediaan faktor pendukung yang optimal bagi pertumbuhan koleksi merupakan salah satu hal yang dapat dilakukan untuk mengoptimalkan pertumbuhannya.

Tanah merupakan salah satu faktor pendukung yang penting bagi pertumbuhan koleksi. Hal ini tidak lepas dari peran penting tanah bagi penyedia hampir semua faktor pertumbuhan tumbuhan, seperti unsur hara, panas, abrasi, kelembapan, dan tempat berpijak perakaran, sehingga pohon dapat berdiri tegak dan kokoh (Mindawati et al. 2006). Kemampuan tanah sebagai media tumbuh akan optimal jika didukung oleh sifat fisika, kimia, dan biologi yang baik (Sartohadi et al. 2012). Informasi kondisi tanah sangat penting bagi manajemen kebun raya, karena jenis tanah, kondisi nutrisi, bahan induk, sifat kimia, biologis, dan fisik tanah mempengaruhi pembentukan dan pertumbuhan koleksi tumbuhan (Gratzfeld 2016). Kesuburan tanah berimplikasi pada pertumbuhan dan kesehatan tumbuhan (Pregitzer et al. 2016), sehingga daya dukung ini perlu dikelola dengan baik.

Kondisi kesuburan tanah sangat penting untuk pengelolaan koleksi di KRB. Pengelolaan area dan koleksi di KRB meliputi pembersihan area, seperti penyapuan, pemupukan (pemberian kompos), pembumbunan, pendangiran (bobokor) pada beberapa koleksi, serta pemotongan rumput pada area-area tertentu. Namun, saat ini kondisi kesuburan tanah di KRB belum diketahui. Melalui penelitian ini diharapkan akan diketahui kondisi kesuburan tanah, meliputi sifat kimia dan fisika tanah.

Penelitian ini bertujuan untuk mengetahui kondisi kesuburan tanah di KRB yang meliputi sifat kimia dan fisika tanah. Hasil penelitian ini diharapkan dapat dijadikan dasar dalam manajemen kesuburan tanah, sehingga koleksi tumbuhan dapat tumbuh dengan optimal.

\section{METODE}

\section{Lokasi dan waktu}

Penelitian ini dilaksanakan pada bulan Maret-Oktober 2019 di Pusat Penelitian Konservasi Tumbuhan dan Kebun Raya, LIPI (Kebun Raya Bogor). Kondisi cuaca rata-rata harian pada saat penelitian adalah sebagai berikut: suhu udara $26,32^{\circ} \mathrm{C}$, kelembapan udara $79,41 \%$, curah hujan $263,48 \mathrm{~mm} /$ bulan, lama penyinaran matahari 7,14 jam, dan kecepatan angin 1,10 m/detik. Luas lokasi pengamatan adalah 87 ha, dengan koordinat $106^{\circ} 47^{\prime} 40^{\prime \prime}-106^{\circ} 48^{\prime} 18^{\prime \prime}$ BT dan 6 $35^{\prime} 32^{\prime \prime}-6^{\circ} 36^{\prime} 13^{\prime \prime}$ LS. Ketinggian tempat adalah $257 \mathrm{~m}$ dpl. 


\section{Pengambilan sampel}

Penelitian dilaksanakan dengan metode survei tanah detail, skala 1:5.000-1:10.000 (Wahyunto et al. 2016) dengan tujuan khusus yaitu kesuburan kimia dan fisika tanah. Penentuan titik sampel berdasarkan hasil overlay dari peta kebun, tutupan lahan, dan kontur (Gambar 1).

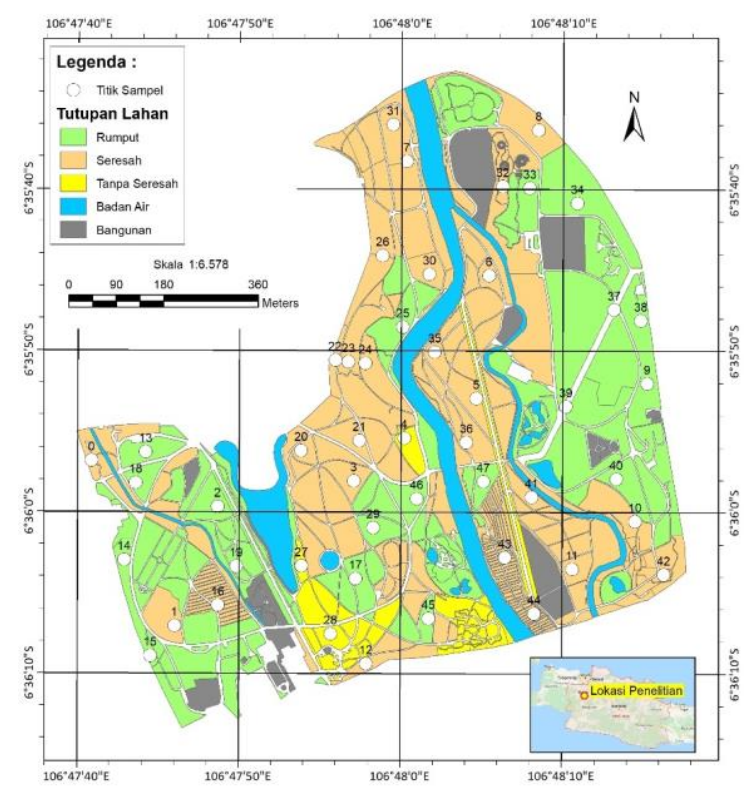

Gambar 1. Peta lokasi penelitian dan pengambilan titik sampel

Overlay dilakukan karena Atlas Peta Tanah Semi Detail Kota Bogor (skala 1:50.000) memetakan lokasi Kebun Raya Bogor (KRB) sebagai pemukiman (BBPPSDLP 2018). Oleh karena itu, peta satuan tanah baru khusus untuk KRB perlu dibuat. Tutupan lahan dikategorikan menjadi tiga tipe, yaitu rumput, serasah, dan tanpa serasah (Gambar 2). Hasil overlay peta tersebut, titik menjadi acuan pengambilan sampel tanah dengan minimal tiga titik per tutupan lahan di antara koleksi tumbuhan (Gambar 2b). Sampel tanah untuk analisis kimia di laboratorium diambil secara komposit dari contoh tanah terganggu, sedangkan analisis fisika tanah menggunakan contoh tanah tak terganggu. Pengambilan contoh tanah dilakukan dengan menggunakan ring sample berdiameter $5 \mathrm{~cm}$ dan kedalaman $0-50 \mathrm{~cm}$.

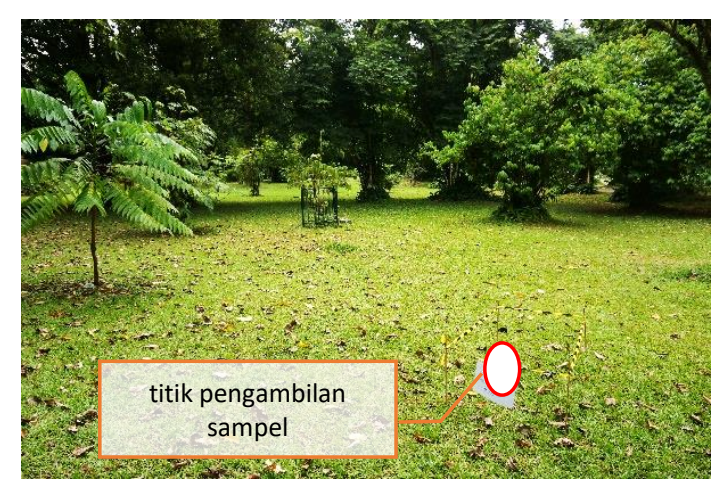

(a)

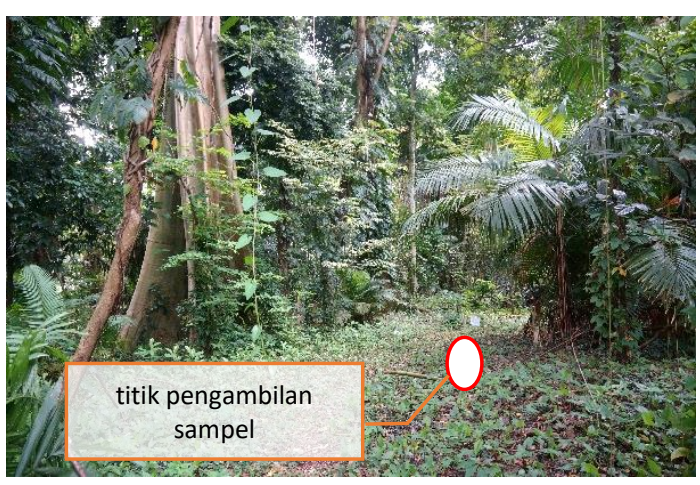

(b)

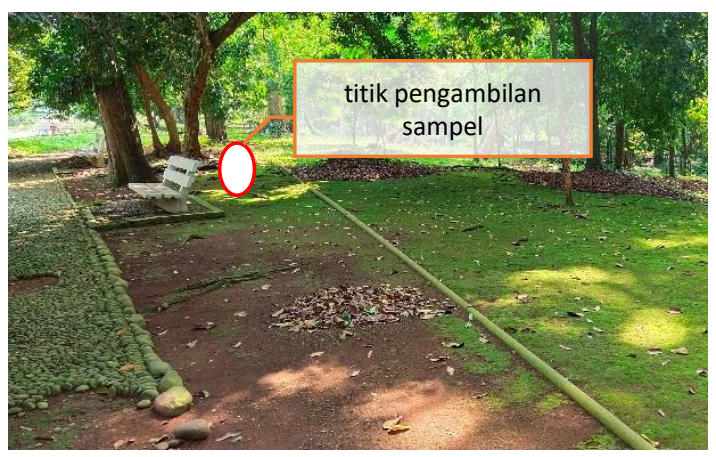

(c)

Gambar 2. Tipe tutupan lahan area koleksi tumbuhan: tutupan dengan rumput (a); tutupan lahan dengan serasah (b); tutupan lahan tanpa serasah (c)

\section{Analisis laboratorium}

Sampel tanah dianalisis di laboratorium Indonesian Center for Biodiversity and Biotechnology (ICBB), Bogor. Variabel pengamatannya adalah tekstur tiga fraksi (metode pipet), $\mathrm{pH}$ (metode potensiometri), kapasitas tukar kation (metode $\mathrm{N}-\mathrm{NH}_{4} \mathrm{OAc} \mathrm{pH}$ 7.0), kandungan nitrogen total (metode Kjeldahl), $\mathrm{P}_{2} \mathrm{O}_{5}$ tersedia (metode Bray I untuk tanah ber-pH asam), $\mathrm{K}_{2} \mathrm{O}$ potensial (metode $\mathrm{HCl} 25 \%$ ), dan C organik (metode Walkley \& Black) (BPT 2009). 


\section{Analisis data}

Kriteria/pengharkatan parameter kesuburan tanah berdasarkan petunjuk analisis kimia tanah, tanaman, air, dan pupuk disajikan dalam Tabel 1
(BPT 2009). Parameter tekstur tanah menggunakan pengharkatan United States Department of Agriculture (USDA) (2020) yang dipadankan dengan penamaan tekstur di Indonesia (Gambar 3).

Tabel 1. Kriteria/ pengharkatan parameter kesuburan tanah

\begin{tabular}{|c|c|c|c|c|c|}
\hline \multirow[b]{2}{*}{ Parameter tanah } & \multicolumn{5}{|c|}{ Nilai } \\
\hline & $\begin{array}{l}\text { Sangat } \\
\text { rendah }\end{array}$ & Rendah & Sedang & Tinggi & Sangat tinggi \\
\hline C organik (\%) & $<1$ & $1-2$ & $2,1-3$ & $3,1-5$ & $>5$ \\
\hline $\mathrm{N}$ total (\%) & $<0,1$ & $0,1-0,2$ & $0,21-0,5$ & $0,51-0,75$ & $>0,75$ \\
\hline $\mathrm{C} / \mathrm{N}$ & $<5$ & $5-10$ & $11-15$ & $16-25$ & $>25$ \\
\hline $\begin{array}{l}\mathrm{P}_{2} \mathrm{O}_{5} \text { tersedia (Bray) } \\
(\mathrm{ppm} \mathrm{P})\end{array}$ & $<4$ & $5-7$ & $8-10$ & $11-15$ & $>15$ \\
\hline $\begin{array}{l}\mathrm{K}_{2} \mathrm{O} \text { potensial }(\mathrm{HCl} 25 \%) \\
(\mathrm{mg} / 100 \mathrm{~g})\end{array}$ & $<10$ & $10-20$ & $21-40$ & $41-60$ & $>60$ \\
\hline KTK/CEC (me/100 g tanah) & $<5$ & $5-16$ & $17-24$ & $25-40$ & $>40$ \\
\hline $\mathrm{pH}$ & $\begin{array}{l}\text { Sangat } \\
\text { masam }\end{array}$ & Masam & $\begin{array}{c}\text { Agak } \\
\text { masam }\end{array}$ & Netral & $\begin{array}{l}\text { Agak } \\
\text { alkalis }\end{array}$ \\
\hline & $<4,5$ & $4,5-5,5$ & $5,6-6,5$ & $6,6-7,5$ & $7,6-8,5$ \\
\hline
\end{tabular}

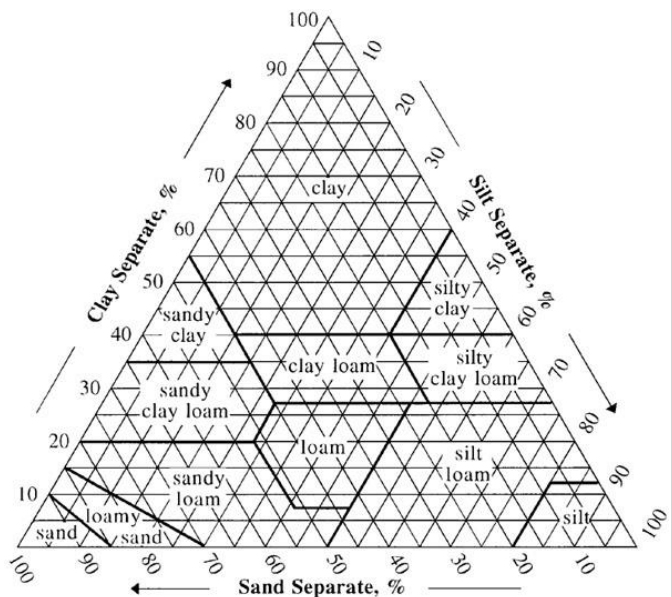

Gambar 3. Segitiga tekstur tanah

Analisis data kompilasi rataan, korelasi antara tutupan lahan dan paremeter kesuburan tanah (tekstur tiga fraksi, pH, kapasitas tukar kation, kandungan nitrogen total, $\mathrm{P}_{2} \mathrm{O}_{5}$ tersedia, $\mathrm{K}_{2} \mathrm{O}$ potensial, dan $\mathrm{C}$ organik) menggunakan software Minitab 16.0 dan Microsoft Excel 2019. Analisis data spasial berupa digitasi, klasifikasi, dan overlay peta menggunakan software ArcGIS 10.3.

\section{HASIL DAN PEMBAHASAN}

\section{Kandungan $\mathrm{C}$ organik, $\mathrm{N}$ total, dan rasio $\mathrm{C} / \mathrm{N}$}

Unsur hara tanah yang diamati meliputi kandungan nitrogen, $\mathrm{C}$ organik, dan rasio $\mathrm{C} / \mathrm{N}$. Kandungan $\mathrm{C}$ organik tertinggi terdapat pada area

\begin{tabular}{|c|c|}
\hline $\begin{array}{l}\text { Padanan: } \\
\text { - clay } \\
\text { - clay loam } \\
\text { - silt } \\
\text { - silt lom } \\
\text { - silty clay } \\
\text { - silty clay loam } \\
\text { - loam } \\
\text { - loamy sand } \\
\text { - sand } \\
\text { - sandy loam } \\
\text { - sandy clay }\end{array}$ & $\begin{array}{l}=\text { klei } \\
=\text { lom klei } \\
=\text { debu } \\
=\text { lom berdebu } \\
=\text { klei berdebu } \\
=\text { lom klei berdebu } \\
=\text { lom } \\
=\text { pasir berlom } \\
=\text { pasir } \\
=\text { geluh berpasir } \\
=\text { lempung berpasir dan clay loam } \\
=\text { geluh lempung berpasir }\end{array}$ \\
\hline
\end{tabular}

Padanan:

- clay loam

silt lom

silty clay

silty clay loam

loamy sand

sandy loam

= geluh lempung berpasir dengan tutupan serasah (4,39\%), sedangkan C organik terendah dijumpai pada area berumput (2,61\%) (Gambar 4). Berdasarkan pengharkatan BPT (2009), persentase sebaran C organik bervarasi, dari sangat rendah $(1,88 \%)$, rendah $(14,80 \%)$, sedang $(39,37 \%)$, tinggi $(35,94 \%)$ dan sangat tinggi $(8,01 \%)$ (Gambar 5a). Kandungan C organik ini dipengaruhi oleh masukan bahan organik dari vegetasi di atasnya. Serasah menjadi penyumbang utama C organik yang berasal dari tumbuhan di atasnya (Bargali et al. 2015). Proses selanjutnya, serasah akan mengalami dekomposisi dan mineralisasi (Aprianis 2011). 


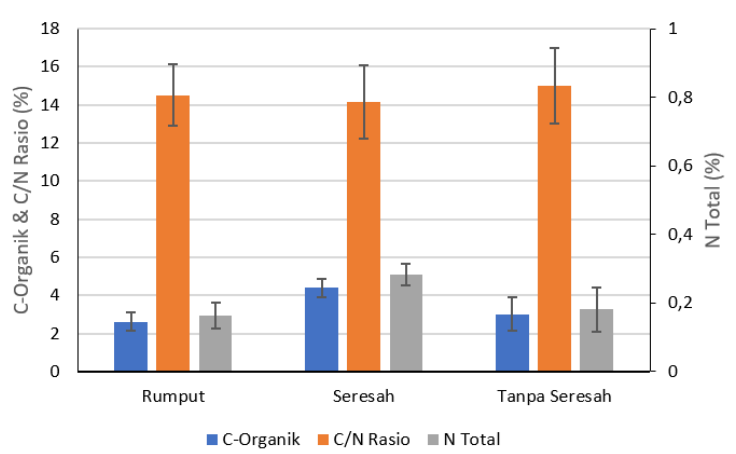

Gambar 4. Kandungan C-organik, $\mathrm{N}$ total, dan rasio $\mathrm{C} / \mathrm{N}$ pada tutupan lahan yang berbeda

Sumber: Hasil analisis laboratorium

Area lahan yang ditutupi serasah didominasi oleh koleksi dengan habitus pohon yang memberikan masukan bahan organik lebih tinggi dibandingkan area tutupan lahan rumput maupun tanpa serasah. Hal inilah yang menyebabkan area tutupan lahan seresah memiliki kandungan C organik paling tinggi bila dibandingkan dengan dua area tutupan lahan lainnya. Sedangkan kandungan C organik pada tutupan lahan tanpa serasah, nilainya lebih tinggi bila dibandingkan dengan area tutupan lahan rumput. Tutupan lahan tanpa serasah sebelumnya memiliki masukan serasah berupa daun dan ranting dari koleksi tumbuhan di atasnya, namun tutupan tersebut dibersihkan. Pada area tutupan lahan rumput, bahan organik dari koleksi tumbuhan berjenis perdu dan rumput. Material tumbuhan dengan jenis rumput-rumputan lebih lama terdekomposisi karena memiliki kandungan selulosa dan lignin (Wahyuni 2013). Minimnya unsur organik yang masuk ke dalam tanah menyebabkan nilai kandungan $\mathrm{C}$ organik di areal tutupan lahan rumput rendah.

Kandungan nitrogen total tertinggi terdapat pada tutupan lahan serasah $(5,09 \%)$ dan terendah pada tutupan lahan rumput (2,94\%). Berbanding lurus dengan kandungan $\mathrm{C}$ organik, semakin tinggi kandungan $\mathrm{C}$ organik, maka semakin tinggi kandungan nitrogen totalnya (Tabel 2). Nitrogen pada tanah dapat bersumber dari bahan organik melalui mekanisme pelapukan sisa tumbuhan, penyematan dari udara (fiksasi $\mathrm{N}$ ), serta tambahan $\mathrm{N}$ dari aktivitas manusia seperti pemberian pupuk (Siahaan et al. 2018).

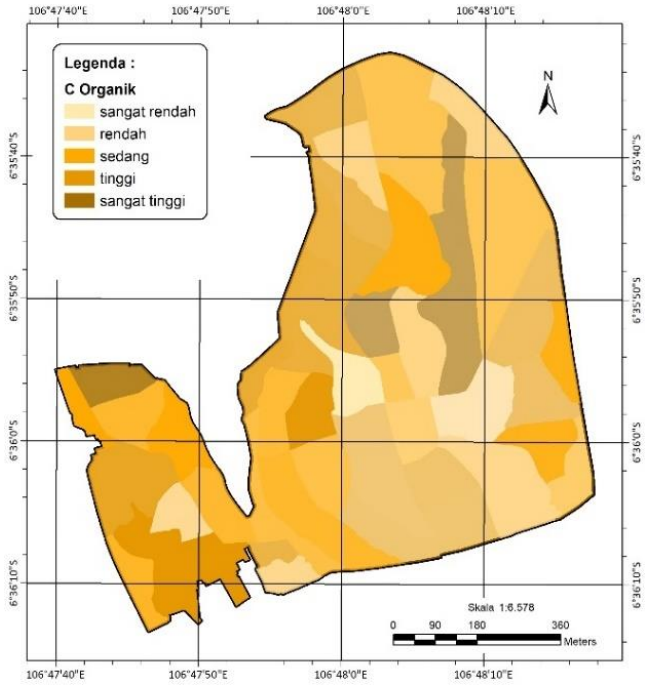

(a)

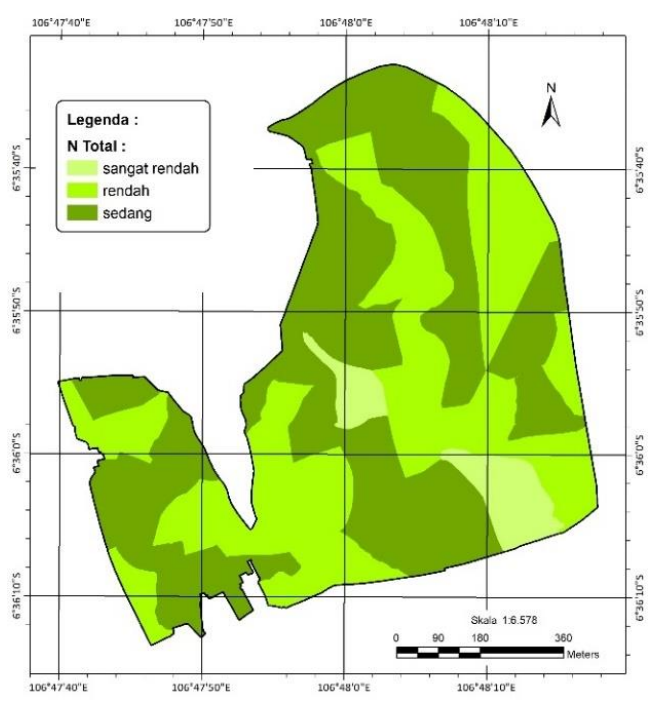

(b)

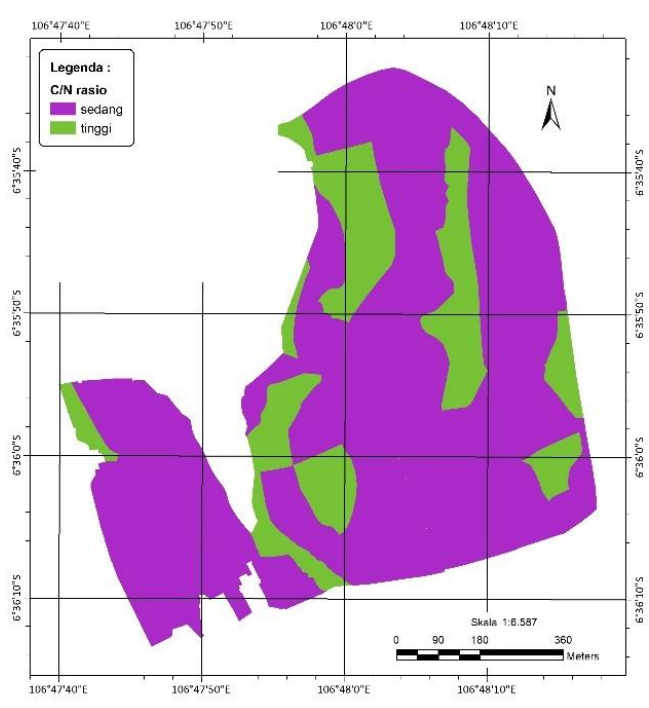

(c)

Gambar 5. Peta sebaran unsur hara. (a) C organik, (b) $\mathrm{N}$ total, dan (c) $\mathrm{C} / \mathrm{N}$ rasio 
Berdasarkan hasil analisis diketahui bahwa sebaran nitrogen total termasuk kriteria sedang $(51,82 \%)$, rendah $(42,45 \%)$, dan sangat rendah $(5,73 \%)$ (Gambar 5b). Hal ini menunjukkan bahwa kandungan nitrogen total pada lokasi penelitian cenderung rendah sampai sedang. Manajemen pengelolaan koleksi saat ini telah dilakukan dengan pemberian pupuk kompos hasil dekomposisi daun dan ranting. Proses pengomposan dilakukan di lokasi lain dengan penambahan mikroba. Akan tetapi, pemberian pupuk kompos belum optimal untuk masing-masing koleksi tumbuhan. Pada saat ini, pemberian pupuk kompos difokuskan pada koleksi tumbuhan yang baru ditanam dan tanaman tertentu. Hal ini dikarenakan belum adanya informasi mengenai kebutuhan hara untuk masingmasing koleksi tumbuhan di kebun raya.

Perbandingan karbon dengan nitrogen total (rasio $\mathrm{C} / \mathrm{N}$ ) tertinggi pada tutupan lahan tanpa serasah $(15,00)$ dan terendah di serasah $(14,12)$ (Gambar 4). Akan tetapi, ketiga nilai $\mathrm{C} / \mathrm{N}$ ratio pada berbagai tutupan lahan termasuk dalam kategori sedang, yaitu dalam rentang 11-15 (Gambar 5c)
(BPT 2009). Hal ini mengindikasikan aktivitas mikroorganisme dalam mendekomposisi bahan organik berjalan normal. Rasio $\mathrm{C} / \mathrm{N}$ yang terlalu tinggi akan memperlambat proses dekomposisi. Jika terlalu rendah, proses dekomposisi berjalan dengan cepat pada awalnya, kemudian pada akan melambat hingga proses berakhir. $\mathrm{Hal}$ ini dikarenakan mikroorganisme akan kekurangan C sebagai sumber energi (Pandebesie \& Rayuanti 2013).

\section{Kandungan kimia tanah}

Parameter kandungan kimia tanah berupa $\mathrm{pH} \mathrm{H}_{2} \mathrm{O}, \mathrm{pH} \mathrm{KCl}, \mathrm{P}_{2} \mathrm{O}_{5}$ tersedia, $\mathrm{K}_{2} \mathrm{O}$ potensial, dan KTK (Tabel 2). Kandungan $\mathrm{pH} \mathrm{H}_{2} \mathrm{O}$ (aktual) pada tutupan lahan yang berbeda tidak memberikan perbedaan yang signifikan. Ketiga tutupan lahan memiliki $\mathrm{pH} \mathrm{H}_{2} \mathrm{O}$ dengan kategori masam, yaitu dalam rentang 4,5-5,5, sedangkan $\mathrm{pH}$ potensialnya $(\mathrm{KCl})$ dapat mencapai kategori sangat masam, yaitu di bawah 4,5 (BPT 2009). Peta sebaran $\mathrm{P}_{2} \mathrm{O}_{5}$ tersedia dan $\mathrm{K}_{2} \mathrm{O}$ potensial disajikan dalam Gambar 6.

Tabel 2. Kandungan kimia tanah pada tutupan lahan yang berbeda

\begin{tabular}{lccrcc}
\hline Tutupan Lahan & $\mathrm{pH} \mathrm{H}{ }_{2} \mathrm{O}$ & $\mathrm{pH} \mathrm{KCl}$ & $\begin{array}{c}\mathrm{P}_{2} \mathrm{O}_{5} \text { tersedia } \\
(\mathrm{ppm})\end{array}$ & $\begin{array}{c}\mathrm{K}_{2} \mathrm{O} \text { potensial } \\
(\mathrm{mg} / 100 \mathrm{~g})\end{array}$ & $\begin{array}{c}\mathrm{KTK} \\
(\mathrm{cmol}(+) / \mathrm{kg})\end{array}$ \\
\hline Rumput & $5,41 \pm 0,33$ & $4,19 \pm 0,21$ & $2,39 \pm 1,75$ & $44,68 \pm 7,99$ & $18,26 \pm 2,40$ \\
Serasah & $5,49 \pm 0,49$ & $4,21 \pm 0,35$ & $12,10 \pm 3,66$ & $74,36 \pm 9,38$ & $22,81 \pm 2,60$ \\
Tanpa Serasah & $5,22 \pm 0,58$ & $4,00 \pm 0,20$ & $1,94 \pm 0,64$ & $60,67 \pm 5,90$ & $18,40 \pm 0,47$ \\
\hline
\end{tabular}

Sumber : Hasil analisis laboratorium

Kandungan $\mathrm{P}_{2} \mathrm{O}_{5}$ tersedia tertinggi pada tutupan lahan serasah $(12,10 \mathrm{ppm})$ dan terendah pada tutupan lahan tanpa serasah (1,94 ppm). Kandungan $\mathrm{P}_{2} \mathrm{O}_{5}$ tersedia ini berkorelasi positif dengan $\mathrm{pH}$ dan $\mathrm{N}$ total (Tabel 3). Tingginya kandungan $\mathrm{P}_{2} \mathrm{O}_{5}$ tersedia pada tutupan lahan serasah dikarenakan tingginya kandungan bahan organik yang menyebabkan meningkatnya proses dekomposisi. Hal yang sama ditemukan pada penelitian Susanti \& Halwany (2017), bahwa penambahan unsur hara dalam tanah selain oleh proses pemupukan, juga dapat bersumber dari proses dekomposisi serasah.

Kandungan $\mathrm{K}_{2} \mathrm{O}$ potensial pada ketiga tutupan lahan dikategorikan tinggi (40-60 mg/100 g) hingga sangat tinggi (>60 mg/100 g). Tingginya kandungan ini dipengaruhi oleh persentase tekstur yang didominasi fraksi klei. Tanah yang memiliki fraksi klei tinggi (33-92\%) cenderung memiliki kadar bahan organik rendah hingga sedang, kadar $\mathrm{K}$ potensial, basa-basa (Ca dan $\mathrm{Mg}$ ), dan kapasitas tukar kation umumnya tinggi (Subagyo et al. 2000). Kapasitas tukar kation tertinggi pada tutupan lahan serasah dan terendah pada tutupan lahan rumput. Hal ini dipengaruhi oleh tingginya kandungan unsur hara nitrogen, fosfor, dan kalium. Sesuai dengan hasil korelasi hubungan $\mathrm{KTK}$ dengan $\mathrm{N}$ dan $\mathrm{K}_{2} \mathrm{O}$ yang termasuk kuat, dan $\mathrm{P}_{2} \mathrm{O}_{5}$ termasuk cukup (Tabel 3 ). 


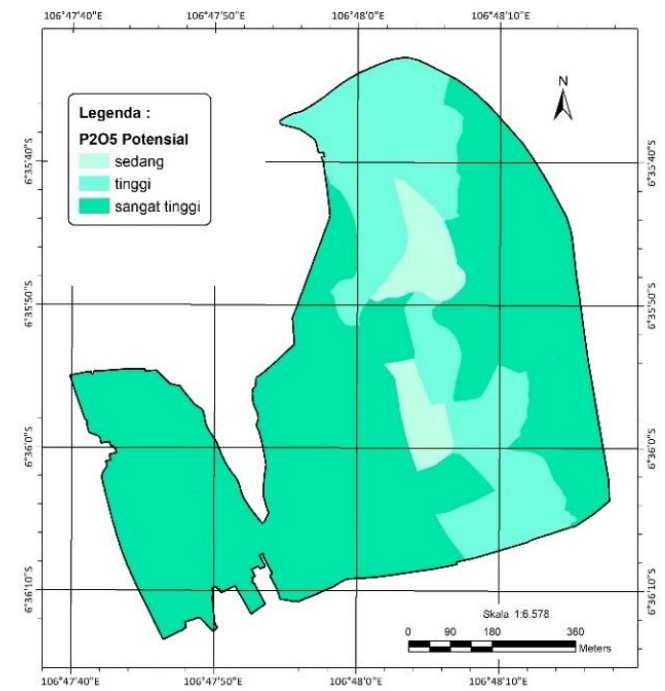

(a)

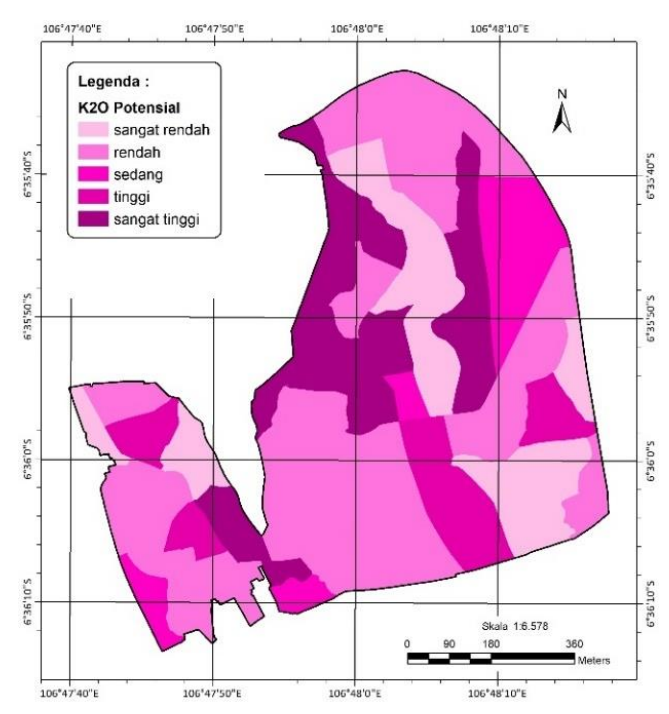

(b)

Gambar 6. Peta sebaran $\mathrm{P}_{2} \mathrm{O}_{5}$ tersedia dan $\mathrm{K}_{2} \mathrm{O}$ potensial

\section{Persentase tekstur tanah}

Gambar 7 menunjukkan peta sebaran kelas tekstur tanah di lokasi penelitian. Tekstur tanah menurut United States Department of Agriculture (USDA) (2020) didominasi oleh klei 76,60\%, selanjutnya lom klei $13,13 \%$, lom 3,85\%, lom klei berpasir $4,63 \%$, dan lom berpasir $1,80 \%$. Tanah yang memiliki tekstur klei mempunyai luas permukaan yang besar, sehingga memiliki kemampuan menahan dan menyimpan unsur hara yang tinggi (Hardjowigeno 2003). Persentase tekstur pada semua tutupan lahan didominasi oleh fraksi klei (Gambar 8). Dominasi ini menjadikan tekstur ketiga tutupan lahan termasuk tanah bertesktur klei.

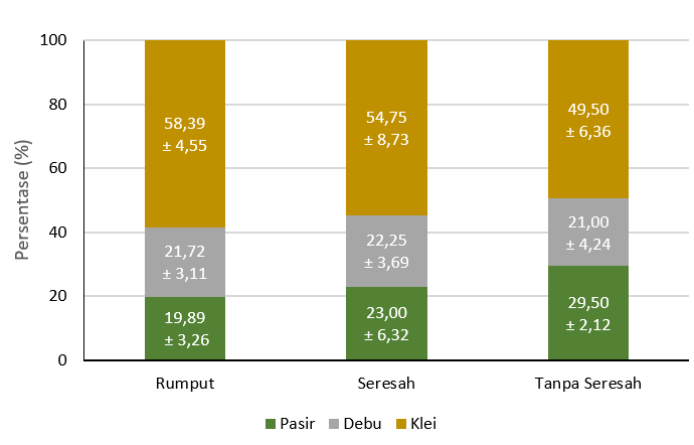

Gambar 7. Persentase tekstur tanah

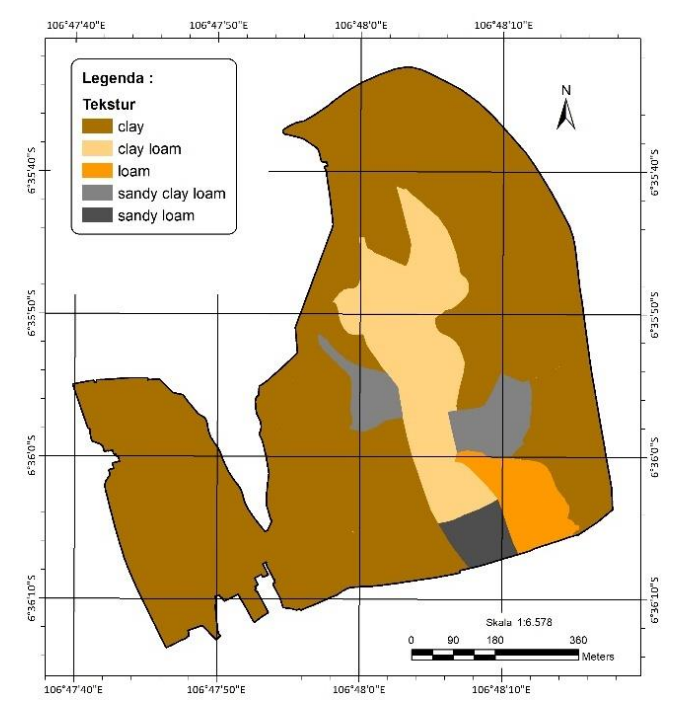

Gambar 8. Peta sebaran tekstur tanah

\section{Korelasi antar variabel pengamatan}

Hubungan antara variabel kesuburan tanah pada tutupan lahan yang berbeda disajikan dalam tabel 3. Hasil analisis korelasi pada 11 variabel pengamatan menunjukkan bahwa ada beberapa parameter yang memiliki nilai korelasi positif dan negatif sangat kuat. Besarnya korelasi -1 adalah negatif sempurna, yakni terdapat hubungan di antara dua variabel atau lebih namun arahnya terbalik. Nilai korelasi +1 adalah korelasi yang positif sempurna (sangat kuat), yakni adanya sebuah hubungan di antara dua variabel atau lebih, sedangkan koefisien korelasi 0 dianggap tidak terdapat hubungan antara dua variabel atau lebih, sehingga dapat dikatakan tidak ada hubungan sama sekali. 
Tabel 3. Korelasi antar variabel pengamatan

\begin{tabular}{|c|c|c|c|c|c|c|c|c|c|c|c|}
\hline & $\begin{array}{c}\mathrm{pH} \\
\mathrm{H}_{2} \mathrm{O}\end{array}$ & $\begin{array}{l}\mathrm{pH} \\
\mathrm{KCl}\end{array}$ & C-organik & $\begin{array}{c}\mathbf{N} \\
\text { Total }\end{array}$ & $\begin{array}{l}\mathrm{C} / \mathrm{N} \\
\text { Ratio }\end{array}$ & $\begin{array}{c}\mathrm{P}_{2} \mathrm{O}_{5} \\
\text { tersedia }\end{array}$ & $\begin{array}{c}\mathrm{K}_{2} \mathrm{O} \\
\text { potensial }\end{array}$ & KTK & Pasir & Debu & Klei \\
\hline $\mathrm{pH} \mathrm{H} \mathrm{H}_{2} \mathrm{O}$ & 1,00 & & & & & & & & & & \\
\hline $\mathrm{pH} \mathrm{KCl}$ & 0,91 & 1,00 & & & & & & & & & \\
\hline C-organik & 0,03 & 0,05 & 1,00 & & & & & & & & \\
\hline N Total & 0,10 & 0,12 & 0,94 & 1,00 & & & & & & & \\
\hline C/N Ratio & $-0,17$ & $-0,21$ & $-0,14$ & $-0,45$ & 1,00 & & & & & & \\
\hline $\mathrm{P}_{2} \mathrm{O}_{5}$ tersedia & 0,60 & 0,57 & 0,39 & 0,59 & $-0,59$ & 1,00 & & & & & \\
\hline $\mathrm{K}_{2} \mathrm{O}$ potensial & $-0,07$ & $-0,16$ & 0,76 & 0,76 & 0,39 & 0,07 & 1,00 & & & & \\
\hline KTK & 0,25 & 0,02 & 0,68 & 0,72 & $-0,20$ & 0,46 & 0,69 & 1,00 & & & \\
\hline Pasir & 0,04 & 0,06 & 0,07 & $-0,07$ & 0,23 & $-0,22$ & 0,39 & 0,10 & 1,00 & & \\
\hline Debu & 0,16 & $-0,03$ & 0,10 & 0,00 & 0,07 & $-0,17$ & 0,19 & 0,49 & 0,16 & 1,00 & \\
\hline Klei & $-0,12$ & $-0,03$ & $-0,10$ & 0,06 & $-0,22$ & 0,26 & $-0,52$ & $-0,35$ & $-0,88$ & $-0,62$ & 1,00 \\
\hline
\end{tabular}

Variabel $\mathrm{C}$ organik, $\mathrm{N}$ total dan $\mathrm{P}_{2} \mathrm{O}_{5}$ tersedia memiliki nilai korelasi positif terbanyak dibandingkan variabel lain, sedangkan variabel fraksi klei memiliki korelasi negatif sangat kuat terhadap fraksi pasir dan debu. Hal ini menyebabkan tekstur tanah didominasi oleh fraksi klei dan kelas teksturnya termasuk clay. Nilai korelasi tertinggi terdapat pada korelasi $\mathrm{pH}_{2} \mathrm{O}$ dan $\mathrm{KCl}(0,91)$, sehingga jika $\mathrm{pH} \mathrm{H}_{2} \mathrm{O}$ (aktual) semakin rendah maka potensi penurunan $\mathrm{pHnya}$ berbanding lurus dengan $\mathrm{pH} \mathrm{KCl}$. $\mathrm{pH} \mathrm{H}_{2} \mathrm{O}$ dan $\mathrm{KCl}$ dapat digunakan sebagai kriteria awal unsur hara dalam tanah. Jika selisih antara $\mathrm{pH} \mathrm{KCl}$ dan $\mathrm{H}_{2} \mathrm{O}$ negatif, berarti tanah tersebut mampu memegang kationkation yang dipertukarkan tumbuhan. Jika nilainya positif, maka dapat diartikan tanah tesebut sangat miskin unsur hara (Prabowo \& Subantoro 2017).

\section{Tingkat kesuburan dan rekomendasi pengelolaan tanah}

Tingkat kesuburan tanah di KRB dapat dikelompokkan berdasarkan overlay parameter kimia tanah, yaitu $\mathrm{C}$ organik, $\mathrm{N}$ total, dan $\mathrm{P}_{2} \mathrm{O}_{5}$ tersedia. Ketiga parameter ini digunakan karena memiliki nilai korelasi positif terbanyak dibandingkan variabel lain (Tabel 3). Persentase tingkat kesuburan tanah di KRB disajikan dalam Gambar 9.

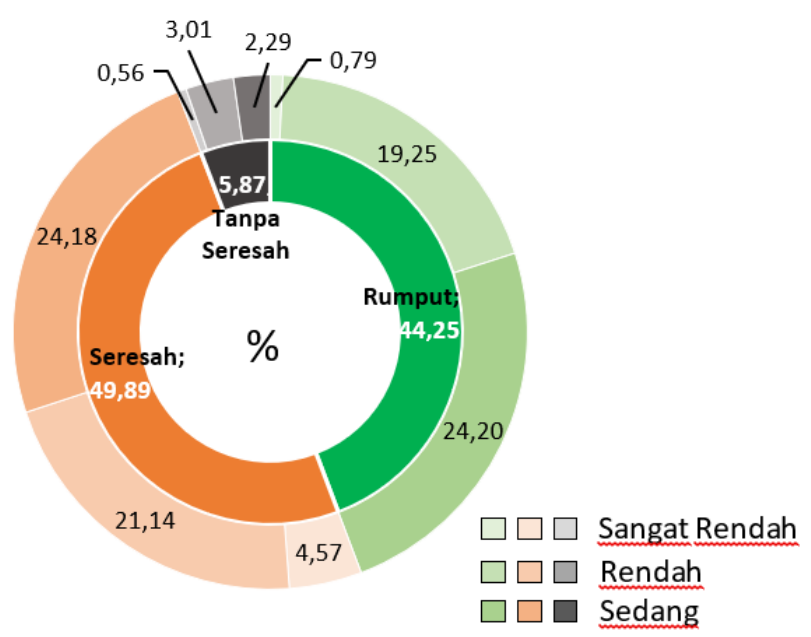

Gambar 9. Diagram tingkat kesuburan tanah di KRB

Kesuburan tanah pada ketiga tutupan lahan mulai dari rendah hingga sedang, dengan jumlah persentase $94,07 \%$ dan sisanya adalah sangat rendah (5,93\%). Tutupan serasah kategori rendahsedang memiliki tingkat kesuburan lebih tinggi dibandingkan tutupan lahan rumput dan tanpa serasah (45,32\%) (Gambar 9). Kondisi ini dapat diartikan bahwa tingkat kesuburan perlu diperhatikan dalam manajemen pengelolaan koleksi. Beberapa masukan hara tambahan diperlukan untuk meningkatkan kesuburan tanah. Rekomendasi yang dapat diberikan sebagai masukan antara lain peningkatan kandungan nitrogen total dengan pemberian pupuk urea atau kompos. Pemberian urea dapat dilakukan pada lokasi dengan kandungan nitrogen total rendah dengan dosis yang disesuaikan jumlah dan umur koleksi.

Rekomendasi kedua dapat dengan cara memberikan kompos. Pemberian kompos dinilai lebih murah, karena KRB telah memproduksi 
kompos secara mandiri. Pengumpulan serasah yang menjadi bahan baku kompos tidak efisien, karena memerlukan tenaga kerja dan waktu, sehingga dapat menambah biaya operasional manajemen koleksi tumbuhan. Teknik pengomposan in situ atau secara langsung di sekitar tajuk dapat menjadi solusi pada tumbuhan kategori pohon. Sisa tumbuhan berupa daun, batang, dan ranting dapat menjadi serasah yang efektif dan efisien dalam menambah kandungan nitrogen.

Serasah dapat diartikan sebagai input material organik yang berasal dari tumbuhtumbuhan di atas tanah yang nantinya dapat menjadi siklus hara dan aliran energi (Chairul 2010). Serasah tumbuhan dapat berupa daun, batang, ranting, dan akar. Menurut Sutedjo et al. (1991), proses dekomposisi serasah adalah peristiwa perubahan secara fisik maupun kimiawi sederhana yang dilakukan oleh mikroorganisme tanah (bakteri, fungi, dan hewan tanah lainnya). Proses ini dapat disebut mineralisasi yaitu proses penghancuran bahan organik yang berasal dari hewan dan tumbuhan yang berubah menjadi senyawasenyawa anorganik sederhana. Proses ini penting dalam siklus ekologi, yaitu sebagai salah satu masukan unsur hara ke dalam tanah. Menurut Vos et al. (2013), proses dekomposisi serasah ini berperan penting dalam siklus karbon dan nutrisi lain.

Sehubungan dengan salah satu fungsi KRB sebagai tempat wisata, maka rekomendasi yang dapat diberikan adalah pembuatan zonasi. Pengunjung diarahkan hanya berkunjung di lokasi area publik, seperti lapangan, meeting point, dan taman. Sedangkan pada zona koleksi, pengunjung hanya dapat berjalan kaki melewati jalan-jalan yang telah disediakan (jalan gico). Dengan demikian, zona koleksi tidak perlu dibersihkan, namun dibiarkan serasahnya jatuh secara alami sebagai masukan hara ke dalam tanah. Sampah organik dari penyapuan jalan dan kebersihan dapat dijadikan pupuk kompos dengan ditambah mikroba dekomposer dan bahan lain untuk meningkatkan kandungan haranya. Kompos yang telah matang dapat diberikan kembali sebagai pupuk organik untuk koleksi tumbuhan.

Pemberian pupuk dapat ditaburkan dalam larikan yang dibuat melingkar dibawah garis tajuk, atau dibenamkan dengan sistem biopori. Kompos dapat diberikan pada saat penanaman di lubang tanam sebagai pupuk dasar. Pada koleksi tumbuhan yang masih muda/baru ditanam, kompos dapat diberikan secara intensif setiap bulan dengan sistem larikan maupun biopori untuk menunjang pertumbuhan yang optimal. Pada koleksi tumbuhan yang tua, kompos lebih optimal diberikan dengan sistem biopori, dengan harapan agar akar lebih mudah menembus tanah, sehingga menambah daya cengkeram akar. Dengan demikian, tanah dapat menjadi sumber hara yang optimal dan menjaga siklus hara tertutup.

\section{KESIMPULAN DAN SARAN}

Kondisi kesuburan tanah di Kebun Raya Bogor dapat dikategorikan rendah hingga sedang (94,07\%). Tutupan serasah kategori rendah-sedang memiliki tingkat kesuburan tanah lebih tinggi dibandingkan tutupan lahan rumput dan tanpa serasah (45,32\%).

Saran yang dapat direkomendasikan adalah peningkatan kandungan nitrogen total dengan pengelolaan zonasi serasah dari koleksi tumbuhan di atasnya. Dengan demikian, diharapkan proses dekomposisi berjalan dengan baik/siklus hara tertutup.

\section{UCAPAN TERIMA KASIH}

Ucapan terima kasih disampaikan kepada koordinator program in house research Pusat Penelitian Konservasi Tumbuhan dan Kebun RayaLIPI yang telah mendanai penelitian ini dan rekanrekan pengawas serta staf pengelolaan koleksi yang telah membantu kegiatan teknis di lapangan.

\section{DAFTAR PUSTAKA}

Agonafir H, Abera MW. 2017. Carbon stock in Gullelebotanical Garden: implication for carbon emission reduction, North Western Addis Ababa, Ethiopia. Journal of Environtment and Earth Science 7(2): 40-52.

Aprianis Y. 2011. Produksi dan laju dekomposisi serasah Acacia crassicarpa A.Cunn. di PT Arara Abadi. Tekno Hutan Tanaman 4(1): 41-47.

Balai Besar Penelitian dan Pengembangan Sumberdaya Lahan Pertanian (BBPPSDLP). 2018. Atlas peta tanah semidetail, skala 
1:50.000, Kota Bogor, Provinsi Jawa Barat. Versi update 2018. Balai Penelitian dan Pengembangan Pertanian, Bogor.

Balai Penelitian Tanah (BPT). 2009. Petunjuk teknis (edisi 2): analisis kimia tanah, tanaman, air, dan pupuk. Balai Besar Litbang Sumber Daya Lahan Pertanian. Badan Penelitian dan Pengembangan Pertanian. Departemen Pertanian, Bogor.

Balai Penelitian Tanaman Serealia (Balitseral). 2017. Bab 12 analisis korelasi. http://balitsereal. litbang.pertanian.go.id. (diakses 1 Juni 2020).

Bargali, Shukla K, Singh L, Ghosh L, Lakhera ML. 2015. Leaf litter decomposition and nutrien dynamics in four tree species of dry deciduous forest. Tropical Ecology 56(2): 191-200.

Botanic Gardens Conservation International (BGCI). 2020. About botanic gardens. https://www. bgci.org/about/about-botanic-garden/. (diakses 27 Mei 2020).

Chairul. 2010. Laju dekomposisi serasah daun beberapa jenis pohon pionir di plot permanen Hutan Penelitian dan Pendidikan Biologi (HPPB) Universitas Andalas Padang. Prosiding Seminar dan Rapat Tahunan BKSPTN Wilayah 2, 10-11 Mei 2010:18-23.

Chen G, Sun W. 2018. The role of botanical garden in scientific research, conservation, and citizen science. Plant Diversity 40(4): 181188. https://doi.org/10.1016/j.pld.2018. 07.00 .

da Costa MLMN, Jackson PW, Fernandes RA, Peixoto AL. 2018. Conservation of threatened plant species in botanic garden reserves in Brazil. Oryx 52(1): 108-115. DOI: 10.1017/S0030605316000776.

Gratani L, Catoni R, Tarquini F. 2019. Carbon dioxide sequestration capability of the Botanical Garden of Rome: environmental and economic benefit. American Journal of Plant Science 10: 1294-1260. DOI: 10.4236/ ajps.2019.108090.

Gratzfeld J. (ed.). 2016. From idea to realisation BGCl's manual on planning, developing and managing botanic gardens. https://www.bgci.org/resources/bgci-toolsand-resources/bgcis-manual-on-planning- developing-and-managing-botanic-gardens. (diakses 23 Mei 2020).

Hadi AA, Mizuuchi Y, Setyanti D, Honjo T, Furuya K. 2017. Identifying visitor preferences for location and features in Bogor Botanical Garden, Indonesia, Using GPS tracking and Geotagged photos. Architecture and Environment 16(1): 47-60. DOI: 10.12962/j2355262x.v16i1.a3029.

Handayani, T. 2016. Musim berbunga dan berbuah jenis-jenis tanaman koleksi suku Annonaceae di Kebun Raya Bogor. Buletin Kebun Raya 19(2): 91-104.

Hardjowigeno S. 2003. Klasifikasi tanah dan pedogenesis. Akademika Pressindo, Jakarta.

Hu Y, Vincent G, Chen X. 2017. How can botanical garden support sustainable urban development? A case study of Shanghai Chenshan Botanical Garden. Annals of the Missouri Botanical Garden 102(2): 303-308. DOI: 10.3417/D-16-00003A.

Irawati, Witjaksono, Nugraheni KU, Isnaini $\mathrm{Y}$, Mursidawati S, Handini E, Gravita RV, Leksonowati A, Rahayu EMD, Wati RK. 2017. In vitro culture of Amorphophallus titanum (Becc.) Becc. ex Archang at Bogor Botanic Garden. Buletin Kebun Raya 20(1): 33-42.

Karasah B, Var M. 2013. Recreational functions of botanical garden and examining sample of nezahat gagyigit botanical garden. International Caucasian Forestry Symposium. Oral Presentation.

Mindawati N, Kosasih AS, Heryati Y. 2006. Pengaruh penanaman beberapa jenis pohon hutan terhadap kondisi kesuburan tanah Andosol. Jurnal Penelitian Hutan Tanaman 3(3): 155164. DOI: 10.20886/jpht.2006.3.3.155-164.

Mounce R, Smith P, Brockington S. 2017. Ex situ conservation of plant diversity in the world's botanic garden. Nature Plants 3: 795-802. DOI: https://doi.org/ 10.1038/s41477-0170019-3.

Oldfield S, Newton AC. 2012. Integrated conservation of tree species by botanic gardens: a reference manual. Botanic Gardens Conservation International, Richmond.

Pandebesie ES, Rayuanti D. 2013. Pengaruh penambahan sekam pada proses 
pengomposan sampah domestik. Jurnal Lingkungan Tropis 6(1): 31- 40.

Peraturan Presiden No. 93 Tahun 2011 tentang Kebun Raya.

Powledge F. 2011. The evolving role of botanical garden. BioScience 61(10): 743-749. https://doi.org/10.1525/bio.2011.61.10.3.

Prabowo R, Subantoro R. 2017. Analisis tanah sebagai indikator tingkat kesuburan lahan budidaya pertanian di Kota Semarang. Jurnal Ilmiah Cendekia Eksakta 2(2): 59-64. doi:http://dx.doi.org/10.3194/ce.v2i2.2087.

Pregitzer CC, Sonti NF, Hallett RA. 2016. Variability in urban soils influences the health and growth of native tree seedlings. Ecological Restoration 34(2): 106-116. DOI: https://doi.org/10.3368/er.34.2.106

Purnomo DW, Helmanto H, Yudaputra A. 2015a. Peran kebun raya Indonesia dalam upaya konservasi tumbuhan dan penurunan emisi karbon. Prosiding Seminar Nasional Masyarakat Biodiversity Indonesia 1(1): 6670. DOI: $10.13057 / p s n m b i / m 010110$

Purnomo DW, Magandhi M, Kuswantoro F, Risna RA, Witono JR. 2015b. Pengembangan koleksi tumbuhan kebun raya daerah dalam kerangka strategi konservasi tumbuhan di Indonesia. Buletin Kebun Raya 18(2): 111124.

Registrasi. 2019. Data koleksi registrasi Kebun Raya Bogor. (Data tidak dipublikasikan).

Sartohadi J, Jamulya, Dewi NIS. 2012. Pengantar geografi tanah. Pustaka Pelajar, Yogyakarta.

Siahaan FA, Irawanto R, Rahadiantoro A, Abiwijaya IK. 2018. Sifat tanah lapisan atas di bawah pengaruh tegakan vegetasi berbeda di Kebun Raya Purwodadi. Jurnal Tanah dan Iklim 42(2): 91-98. DOI: http://dx.doi.org/ 10.2017/jti.v42n2.2018.91-98.

Susanti PD, Halwany W. 2017. Dekomposisi serasah dan keanekaragaman makrofauna tanah pada hutan tanaman industri Nyawai (Ficus variegata Blume). Jurnal IImu Kehutanan 11(2): 12-223. DOI: https://doi.org/ $10.22146 /$ jik.28285.

Subagyo $H$, Suharta N, Siswanto AB. 2000. Tanahtanah pertanian di Indonesia. Dalam Sumber Daya Lahan Indonesia dan Pengelolaannya. Pusat Penelitian Tanah dan Agroklimat, Bogor.
Sutedjo MM, Kartasapoetra AG, Sastromodjo RS. 1991. Mikrobiologi Tanah. PT Rineka Cipta, Jakarta.

United States Department of Agriculture (USDA). 2020. Soil texture calculator. https://www.nrcs.usda.gov/wps/portal/nrcs /detail/soils/survey/?cid=nrcs142p2_05416 7. (diakses 20 Mei 2020).

Vos VCA, Ruijven JV, Berg MP, Peeters THM, Berendse F. 2013. Leaf litter quality drives litter mixing effect through complementary resource use among detritivores. Oecologia 173(1): 269-280. DOI: https://doi.org/ 10.1007/s00442-012-2588-1.

Wahyuni S. 2013. Biogas energi alternatif pengganti bbm, gas, dan listrik. PT. Agro Media Pustaka, Jakarta Selatan.

Wahyunto, Hikmatullah, Suryani E, Tafakresnanto C, Ritung S, Mulyani A, Sukarman, Nugroho K, Sulaeman $Y$, Suparto, Subandiono RE, Sutriadi T, Nursyamsi D. 2016. Petunjuk teknis pedoman survei dan pemetaan tanah tingkat semi detail skala 1:50.000. Balai Besar Penelitian dan Pengembangan Sumberdaya Lahan Pertanian, Badan Penelitian dan Pengembangan Pertanian, Bogor.

Widyatmoko D, Risna RA. 2017. A role of Indonesian Botanic Garden in achieving global strategy for plant conservation goal. Annals of the Missouri Botanical Garden 102(2): 377-385. DOI: 10.3417/D-16-00006A.

Yang $X$, Chen J. 2017. Using discovery maps as a free-choice learning process can enhance the effectiveness of environmental education in a botanical garden. Environmental Education Research 23(5): 656-674. DOI: 10.1080/13504622. 2015.1076766.

Yudaputra A, Zulkarnaen RN, Rachmadiyanto AN, Witono JR, Astuti IP. 2017. Reproduction phenology of Hydriastele beguinii (Burret) W.J. Baker \& Loo. at Bogor Botanical Garden. Buletin Kebun Raya 20(1): 111-118.

Zahriyani P, Yuwono AS. 2014. Absorption capacity of $\mathrm{CO}_{2}, \mathrm{NO}_{2}$, and dustfall emission from transportation, industry and livestock sector in Bogor City by Bogor Botanic Garden. ARPN Journal of Science and Technology 4(6): 379387. 
Zelenika I, Moreau T, Lane O, Zhao J. 2018. Sustainability education in a botanical garden promotes environmental knowledge, attitudes and willingness to act. Environmental Education Research 24(11): 1581-1596. DOI: 10.1080/13504622.2018. 1492705. 